\title{
DEVELOPMENT OF A VACUUM PRECISION SEEDER PROTOTYPE FOR ONION SEEDS
}

\section{Shaaban UA* Afify M T ${ }^{* *}$ Hassan G E ${ }^{* * *}$ El-Haddad ZA**** \\ ABSTRACT}

The purpose of this study was to develop, construct and test a vacuum precision seeder prototype suitable for onion seeds. The developed prototype was fabricated from local materials (Stainless Steel 304). It was also designed to plant two rows with $70 \mathrm{~mm}$ apart instead of one row as the most onion vacuum seeders in the market. Tests were conducted at an indoor soil bin facility under different operational parameters. These parameters were three seed plates with different hole diameters (0.8, 1.0 and $1.2 \mathrm{~mm})$, four levels of disc speeds (peripheral velocity of seed plate) (0.08 (7.3), 0.14 (12.5), 0.21 (18.7) and $0.28 \mathrm{~m} / \mathrm{s}$ (24.4-rpm)), four levels of blower speeds (4000, 4500, 5000 and 5500-rpm) and three level of forward speeds (2.7, 3.6 and $5.3 \mathrm{~km} / \mathrm{h})$. Measurements were taken for the actual seed spacing, seed miss index, seed multiple index, quality of feed index, precision in spacing and the vacuum pressure in the hole. Results indicated that the optimum values of the actual seed spacing (5.93 mm), seed miss index (8.1\%), seed multiple index (8.12\%), quality of feed index (83.7\%), precision in spacing (23.4\%) and the vacuum pressure in the hole (4.75 $\mathrm{kPa}$.) were obtained with the seed plate of $1.0 \mathrm{~mm}$ hole diameter. Results of statistical analysis showed that the most desirable conditions in terms of operating developed prototype were obtained with the seed plate of $1.0 \mathrm{~mm}$ hole diameter at $0.21 \mathrm{~m} / \mathrm{s}$ (18.7-rpm) disc speed, 4500-rpm blower speed and at $3.6 \mathrm{~km} / \mathrm{h}$ forward speed. It also indicated that there was no appreciable difference between the two rows of the developed prototype under different operational conditions.

\section{INTRODUCTION}

nion is considered as the one of the major export vegetable crops in Egypt. The total cultivated area of onion crop is about 111,000 Feddans. This area produced about 1.4 million tons. Most of this area (84\%) is cultivated in the old land by tradition methods. ****Professor, ** Lecturer, *Graduate Student, Dept. of Agric. Eng. Moshtohor, Benha Uni. ***Director of The Agric. Eng. Res. Institute, ARC,Dokki, Giza, Egypt 
Results of several studies indicated that, there are many disadvantages of planting onion by traditional methods (El-Sahrigi, 1985) as a compared with the mechanized methods. Moreover, there was another problem associated with using the imported mechanical machines of planting onion seeds under Egyptian conditions due to the following reasons: 1) the design of these machines is not suitable to plant most of the local onion seeds, 2) they did not give the appropriate plant populations, especially for export fresh shoots onion production, and 3) they are not proper for small holdings in terms of power, size and cost.

There are two common types of precision seeders used in mechanical planting of fine seeds. These were the belt-type and the vacuum-type seeders. The vacuum seeders have a metering plate with metering holes on a predetermined radius. A vacuum is applied to these metering holes by means of a race machined in a backing plate. As the plate rotates, the vacuum applied to the metering holes enables them to pick up seeds from the seed hopper. Therefore, the vacuum seeders have the following advantages compared with the belt-type seeders: 1) better working quality, 2) more precise seed rates with lower rate of seed damage, 3) better control and adjustment of upkeep and drift of seeds, and 4) broader spectrum of applicability (Soos et al., 1989). Several factors affecting on the uniformity of seed spacing using the vacuum-type seeders for fine seeds. These were the produced vacuum pressure, physical and mechanical properties of seeds, the design feature of the metering mechanisms, seed quality, soil conditions, seeder design, the skill of the operator and the operational conditions. Therefore, the main objective of this paper was to design, construct and test a vacuum precision seeder prototype suitable for onion seeds using local materials to meet the following requirement: 1) plant two rows with $70 \mathrm{~mm}$ apart instead of one row, 2) generate a suitable vacuum pressure to pick the seed for the two rows, 3) place the seed at proper distance.

El-Shal (1987) reported that using the mechanical metering mechanisms cause seed damage due to the friction forces between the mechanical parts and the seeds. He added that the pneumatic metering mechanisms may deal gently with the seeds and no damage during planting can occur. He also studied the effect of disc speed and vacuum suction on the seed 
seed uniformity for sunflower and sesame seeds. He found that the optimum uniformity of seed distribution was obtained at 15 -rpm disc speed for both seeds. The suitable vacuum suctions were 0.04 and 0.01 $\mathrm{kg} / \mathrm{cm}^{2}$ for sunflower and sesame seeds, respictively. Bosoi et al., (1987) reported that any planting machine must have hoppers with an optimum capacity in order to feed seeds uniformly and continuously to the seeds metering mechanism. They added that the trapezoidal form is the most widely used hoppers of planting machines.

To optimize the design and operating parameters for cotton seed planting, Singh and Sarawat (2005) found that the lower miss indices were observed at higher vacuum pressure and lower disc speed. However, lower multiple indices were obtained at lower vacuum pressure and higher disc speed. They added that the highest values of the quality of feed index $(94.7 \%)$ were obtained at $0.42 \mathrm{~m} / \mathrm{s}$ disc speed and at $2 \mathrm{kPa}$ vacuum pressure. The lowest values of coefficient of variation in spacing $(8.6 \%)$ were obtained at $0.42 \mathrm{~m} / \mathrm{s}$ disc speed and at $2 \mathrm{kPa}$ vacuum pressure. Lan et al., (1999) developed an Opto-electronic seed spacing measurement system for fine seeds. This system measured time intervals between the seeds and detected front and back seed drop location events to determine the seed spacing uniformity of a planter in the laboratory. The space measurement obtained based on time intervals between seeds drop events were strongly correlated with the space measurements obtained on a greased belt test stand. They added that the accuracy of seed spacing is depending upon the size of the seeds. Onal (1987) reported that the fine seed distribution uniformity depends on the constructional properties and materials of seed tubes and the physical properties of seeds. In the application, the vertical angle of the seed tube must not be bigger than $15^{\circ}$.

Parish et al., (1991) compared between two types of precision seeders. They found that a belt-type seeder resulted in the better uniform seed spacing of spherical seed such as cabbage seed, but spacing of elongated seeds such as cucumber seed was more uniform with a vacuum seeder. Bracy and parish (1998) assessed the uniformity of metering sizegraded and un-graded turnip seeds with precision belt-type and vacuumtype seeders. They concluded that the belt-type seeder should effectively 
cingulated the seeds if the seeds are spherical and uniform because the holes are specifically sized. Seeds that are not graded for size uniformity may not be simulated effectively by a belt-type seeder. A vacuum-type seeder should meter a wider range of seed size more uniformly than a belt-type seeder, since the holes in the seed plate must only be smaller than smallest seeds in the lot.

Barut and Ozmerzi (2004) studied the effect of the peripheral velocity of seed plate on the seed holding ratio for maize. They found that an increase in the peripheral velocity of the seed plate gave a decreased of seed holding ratio for different maize varieties. The effect of planting speed on metering and seed accuracy was studied by Chhinnan et al., (1975). They found that higher planting speeds resulted in more skips, higher speed placement errors, and higher average spacing. Giannini et al., (1967) developed a vacuum-type seeder for precision planting of lettuce that used vacuum principles for planting single seeds. They compared the precision seeder with the standard bulk metering seeder and they found that the vacuum seeder used less seeds and also it is reduced time and resulting in improved yields. Wanjura and Hudspeth (1969) found that pattern efficiency of vacuum plate differed most at lower or higher vacuum pressures and faster wheel speeds. They also found that the $8 \mathrm{~mm}$ seed drop height consistently produced a better seed pattern than $15 \mathrm{~mm}$ drop height with a precision vacuum seeder. They recommended that the metering device on a seeder should be located as low as possible and that seed should fall freely to the bottom of the soil trench.

Karayel and Ozmerzi (2001) stated that the variability in seed spacing with a precision vacuum seeder increased with increasing forward speed. They found that a forward speed of $1.0 \mathrm{~m} / \mathrm{s}$ consistently produced a better seed pattern than 1.5 and $2.0 \mathrm{~m} / \mathrm{s}$ for precision planting of melon and cucumber seeds. Kachman and Smith (1995) stated alternative measurements of accuracy in seed placement for seeders. These measurements based on the theoretical seed spacing and include the multiple index, miss index, quality of feed index and the precision in spacing. They recommended using these measurements for summarizing 
the uniformity of seeder metering rather than meaning or sampling coefficient of variation.

\title{
MATERIALS AND METHODS
}

\section{Prototype Description}

A developed single precision vacuum seeder prototype (Figure 1) consists of the following components.

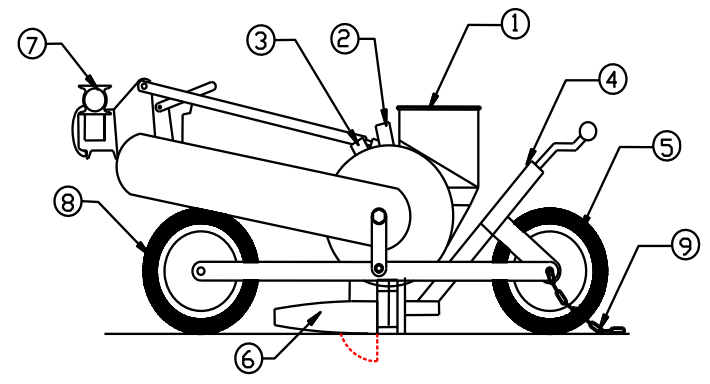

\author{
1- seed box \\ 2- inlet vacuum for the first row \\ 3- inlet vacuum for the second row \\ 4- depth control mechanism \\ 5- rear press wheel \\ 6- furrow opener \\ 7- hitching point \\ 8- front press wheel \\ 9- covering device
}

Figure 1. Schematic diagram of the developed prototype.

\section{Seed box and seed chamber}

The seed box (Figure 2a) has a trapezoidal shaped in the lower part and a rectangular shaped at the upper part. The lower part is inclined $63^{\circ}$ from the vertical direction. The shape of the seed chamber is triangular shape and it designed to be connected with the seed box for receiving the seeds from seed box and transfer the seeds to the holes on the seed plate.

\section{Vertical seed plate and the plate of vacuum flow}

Three seed plates (Figure $2 b$ ) were fabricated with different hole diameters. The hole diameters were $0.8,1.0$ and $1.2 \mathrm{~mm}$. The holes in each seed plate were drilled into two rows. Since the developed prototype was designed to plant two rows, the pitch circle diameters were $190 \mathrm{~mm}$ and $165 \mathrm{~mm}$ for the first and the second rows, respectively. The number of holes in each row was 80 holes. The plate of vacuum flow (Figure 2c) was fabricated from sort of plastics called (Teflon) with outer diameter of $220 \mathrm{~mm}$ and $8 \mathrm{~mm}$ thickness. Two vacuum canals were drilled into the plate to enable the developed seeder prototype to plant two rows. The cross-sectional areas of vacuum canals were $226.95 \mathrm{~mm}^{2}$ and $176.6 \mathrm{~mm}^{2}$ for the first and the second rows, respectively. 


\section{Brush-off device}

Two rigid brush-off devices were fabricated from rubber material and fixed in the back of the seeder case prated $2 \mathrm{~mm}$ from the pitch circle diameters of seed plate for the two rows. The two brush-off devices were curved shape with the radius of curvatures of 88 and $76 \mathrm{~mm}$ (Figure 2d). The dimensions of the brush-off device were 70, $75 \mathrm{~mm}$ length and $5 \mathrm{~mm}$ thickness for the first and the second rows, respectively.

\section{Depth control device}

The depth control device consists of two press wheels with a linkage between them. The diameter of both press wheels is $280 \mathrm{~mm}$. The planting depth is changing by means of a rotating locking mechanism (Figure 1) attached with the front and rear press wheels.

\section{Furrow opener}

A runner-type opener (Figure 2e) with two outlets was used to enable the developed prototype to plant two rows instead of one row. The cutting edge of the opener is $20 \mathrm{~mm}$ width and $114 \mathrm{~mm}$ length. The total length of the furrow opener was $195 \mathrm{~mm}$ and $110 \mathrm{~mm}$ height.

\section{Blower (vacuum pump)}

The blower (vacuum pump) was developed according to the design of the Keverneland vacuum seeder blower. It was fabricated from the local plain carbon steel with $3 \mathrm{~mm}$ thickness. The dimensions of the blower shell and the centrifugal fan are shown in Figures ( $2 \mathrm{f}$ and $2 \mathrm{~g}$ ).

\section{Experimental Procedures}

Tests were conducted at an indoor soil bin facility of the Department of Agricultural Engineering, Mansoura University during the year 2007. The precision vacuum seeder prototype was tested under the following parameters:

- Four levels of blower speeds (4000, 4500, 5000 and $5500 \mathrm{rpm})$.

- $\quad$ Three seed plates with different hole diameters $(0.8,1.0$ and 1.2 $\mathrm{mm}$ hole diameters).

- Four levels of disc speeds (peripheral velocity of seed plate) (0.08 (7.3), 0.14(12.5), 0.21(18.7) and $0.28 \mathrm{~m} / \mathrm{s}(24.4 \mathrm{rpm})$ ).

- Three forward speeds $(2.7,3.6$ and $5.3 \mathrm{~km} / \mathrm{h})$. 


\section{Dim. in mm.}
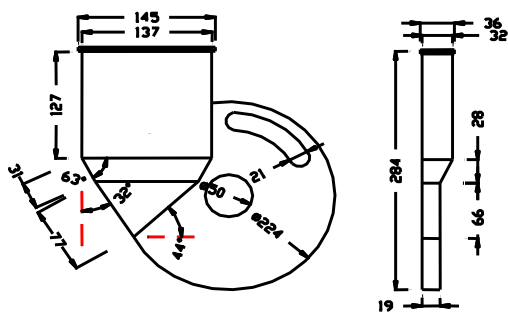

(a) seed box and seed chamber

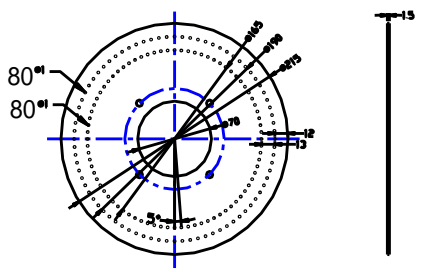

(b) seed plate
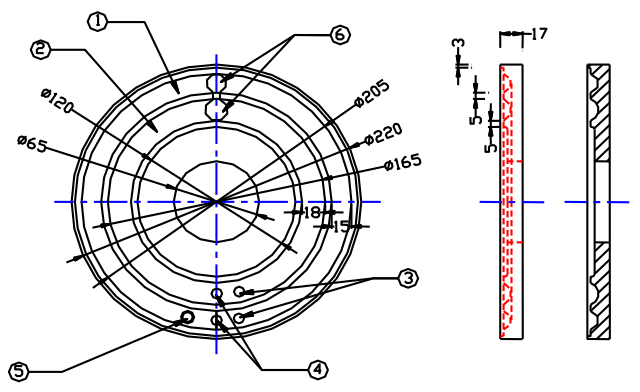

1- vacuum canal for first row

2- vacuum canal for second row

3- air cut for two rows

4- holes for cleaning seed plate

5- closing thread hole

6- inlet air for tow rows

(c) plate of vacuum flow

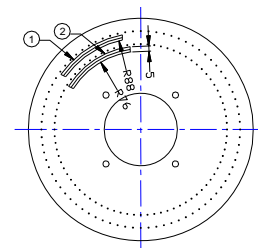

(d) brush-off device

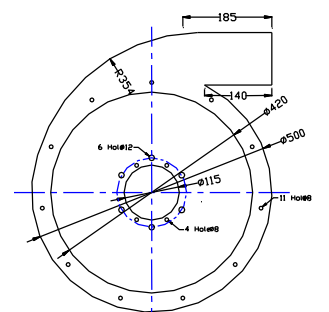

(f) blower shell

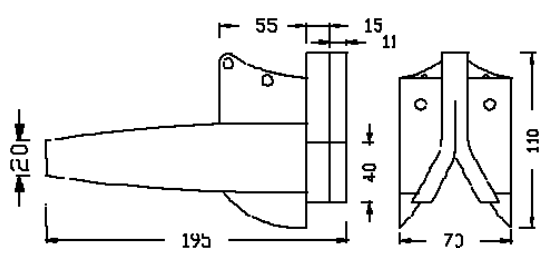

(e) runner-type furrow opener
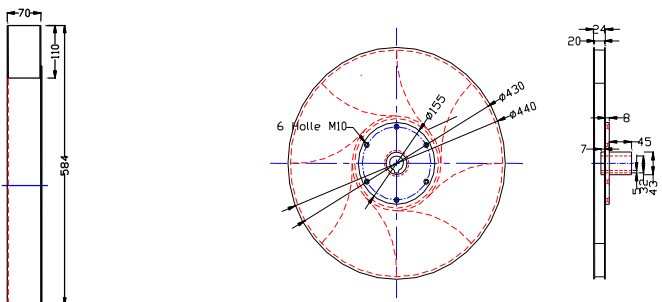

(g) centrifugal fan

Figure 2. Schematic diagram of the individual components of the developed prototype. 
The soil bin was $0.75 \mathrm{~m}$ wide, $5.7 \mathrm{~m}$ long and $0.4 \mathrm{~m}$ depth. The movable carriage has a length of $700 \mathrm{~mm}$ and $300 \mathrm{~mm}$ width. The vacuum precision seeder was mounted in the centerline of the bottom carriage by means of link was made of steel square bars of $(60 \times 60 \mathrm{~mm})$ and 300 $\mathrm{mm}$ length. The soil in the bin was sandy soil. The elements of soil bin powered by means of three variable speed drive electric motors. The first motor $(0.25 \mathrm{~kW})$ was used to rotate the seed plate. The second motor $(2.3 \mathrm{~kW})$ was used to drive the soil bin carriage and provide it with different forward speeds. The third motor $(3.7 \mathrm{~kW})$ was used to derive the blower (vacuum pump).

The theoretical (nominal) seed spacing was calculated for the three seed plates under various levels of disc speeds and forward speeds using the following equation:

$$
X_{s}=\frac{60 \times v}{\lambda_{c} \times n} \quad \text { (Srivastava et al., 1993) }
$$

Where:

$$
\begin{aligned}
& \mathrm{X}_{\mathrm{s}}=\text { theoretical seed spacing along the row, }(\mathrm{m}), \\
& \mathrm{v}=\text { forward speed, }(\mathrm{m} / \mathrm{s}), \\
& \lambda_{\mathrm{c}}=\text { number of seed delivered per revolution of the metering } \\
& \quad \text { mechanism, and } \\
& \mathrm{n}=\text { rotational speed of metering mechanism, }(\mathrm{rpm}) .
\end{aligned}
$$

Measurements were taken for the actual mean seed spacing, seed miss index, seed multiple index, quality of feed index, precision in spacing and the vacuum pressure in the hole. The actual seed spacing was determined along the row for each run and measured thee times over a distance of $3 \mathrm{~m}$ long. Data of the actual and theoretical seed spacing were used to get the seed miss index, seed multiple index, quality of feed index, and the precision in spacing under different operational parameters. The seed miss index is the percentage of spacing greater than 1.5 times the theoretical spacing and indicates the percentage of missed seed locations or 'skips'. The seed multiple index is the percentage of spacing that are less than or equal to half of the theoretical spacing and indicates the percentage of multiple seed drops. The quality of feed index is the percentage of spacing that are more than half but no more than 1.5 times the theoretical spacing. The precision in spacing is the coefficient 
of variation of the spacing that is classified as singles after omitting the outliers consisting of misses and multiples. The vacuum pressure in the hole was measured using a manometer with an accuracy of 1.0-mbar (100 Pa.) under different levels of blower speeds and by using the three seed plates.

\section{RESULTS AND DISCUSSION \\ The actual seed spacing}

Figure (3a) shows the actual seed spacing with different hole diameters for the two rows of the developed prototype. The highest values of the actual seed spacing were obtained with the seed plates of 0.8 and $1.0 \mathrm{~mm}$ hole diameters for the two rows. However, the seed plate of $1.2 \mathrm{~mm}$ hole diameter produced the lowest values of the actual seed spacing. The closest values of actual seed spacing in relation to the nominal seed spacing were obtained with the seed plate of $1.0 \mathrm{~mm}$ hole diameter for the two rows. On the other hand, the difference between the nominal and the actual seed spacing with 0.8 and $1.2 \mathrm{~mm}$ hole diameters does not exceed by more then $13 \%$ for the two rows. These results duo to that the hole diameter of $1.0 \mathrm{~mm}$ is equal to $50 \%$ of the geometric mean diameter $(2.02$ $\mathrm{mm}$ ) of onion seed, which resulting a highest values of seed spacing. The effect of the blower speed on the actual seed spacing for the two rows is shown in Figure (3b). It indicates that there was none potential difference in the actual seed spacing under different levels of blower speeds for the two rows. This result due to that the optimum vacuum pressure required to pick up the onion seed does not increase by more than $1.5 \mathrm{kPa}$. (Karayel et al, 2004). However, the minimum predicted vacuum pressure for picking up the seed under this study resulted at low level of blower speed was $2.03 \mathrm{kPa}$ with $1.2 \mathrm{~mm}$ hole diameter (Shaaban, 2009)

Figure (3c) represents the actual seed spacing with different disc speeds for the two rows. The actual seed spacing decreased as the disc speed increased. The highest values of the actual seed spacing were obtained at $0.08 \mathrm{~m} / \mathrm{s}$ disc speed for the two rows. However, the disc speed of 0.28 $\mathrm{m} / \mathrm{s}$ resulted in the lowest values of the actual seed spacing. The closest value of actual seed spacing in relation to the nominal seed spacing was obtained at 0.21 and $0.28 \mathrm{~m} / \mathrm{s}$ disc speeds for the two rows. These results duo to that the ratio of speed reduction between the forward speed and the 
disc speed decreased with an increase in the disc speed at any level of forward speed, which may cause decreasing in the actual seed spacing. The relation between the actual seed spacing with the different forward speeds is shown in Figure (3d). It indicates that the actual seed spacing increased as the forward speed increased for the two rows. In a comparison between the nominal and the actual seed spacing at different forward speeds, the $3.6 \mathrm{~km} / \mathrm{h}$ forward speed resulted in the closest values of the actual seed spacing as a compared with 2.7 and $5.3 \mathrm{~km} / \mathrm{h}$ forward speeds for the two rows. These results are in agreement with previous finding by Karayel and Ozmerzi (2001).

Multi-regression analysis were carried out to derive a relation between the actual seed spacing with respect to forward speed, blower speed and disc speed at different hole diameters for the two rows under experimental conditions. The derived equations are:

For $0.8 \mathrm{~mm}$ hole diameter

$\mathrm{ASS}=3.9+6.58 \mathrm{FS}-0.00130 \mathrm{BS}-0.318 \mathrm{DS}-0.000531 \mathrm{FS} * \mathrm{BS}-0.247$

FS*DS - 0.000071 BS*DS - 0.194 $\mathrm{FS}^{2}+0.0205 \mathrm{DS}^{2}+0.0000002 \mathrm{BS}^{2}$

$+0.000035 \mathrm{FS} * \mathrm{BS} * \mathrm{DS} \quad\left(\mathrm{R}^{2}=96.2 \%\right)$

For $1.0 \mathrm{~mm}$ hole diameter

$\mathrm{ASS}=3.48+4.50 \mathrm{FS}-0.107 \mathrm{BS}-0.551 \mathrm{DS}-0.0185 \mathrm{FS} * \mathrm{BS}-0.0617 \mathrm{FS} * \mathrm{DS}-$

$0.00115 \mathrm{BS} * \mathrm{DS}-0.136 \mathrm{FS} 2+0.0171 \mathrm{DS} 2+0.00171 \mathrm{BS} 2+0.00002$

$\mathrm{FS} * \mathrm{BS} * \mathrm{DS} \quad(\mathrm{R} 2=97.4 \%)$

For $1.2 \mathrm{~mm}$ hole diameter

$\mathrm{ASS}=13.5+1.34 \mathrm{FS}-0.00283 \mathrm{BS}-0.813 \mathrm{DS}+0.000128 \mathrm{FS} * \mathrm{BS}-0.016$

$\mathrm{FS} * \mathrm{DS}+0.000082 \mathrm{BS} * \mathrm{DS}+0.085 \mathrm{FS} 2+0.0153 \mathrm{DS} 2+0.0000002$

BS2 - 0.000015 FS*BS*DS $\quad(\mathrm{R} 2=95.7 \%)$

Where:

ASS $=$ actual seed spacing, $(\mathrm{cm})$,

$\mathrm{FS}=$ forward speed $(\mathrm{km} / \mathrm{h})$,

$\mathrm{BS}=$ blower speed $(\mathrm{rpm})$, and

$\mathrm{DS}=$ disk speed $(\mathrm{rpm})$.

\section{The seed miss index}

Figure (4) shows the effect of hole diameter, blower speed, disc speed and the forward speed on the seed miss index for the two rows of the developed prototype. The seed miss index increased with an increase in 
the hole diameters for the tow rows (Figure 4a). The highest values of the seed miss index were obtained with the seed plate of $1.2 \mathrm{~mm}$ hole diameter for the two rows. However, the hole diameters of 0.8 and 1.0 $\mathrm{mm}$ resulted in the lowest and the middle values of the seed miss indices, respectively. These results may have been due to the following reasons.

(a)

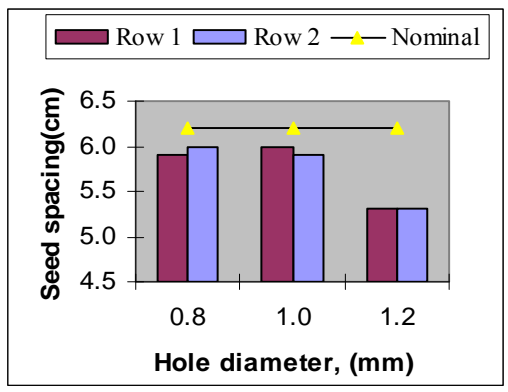

(c)

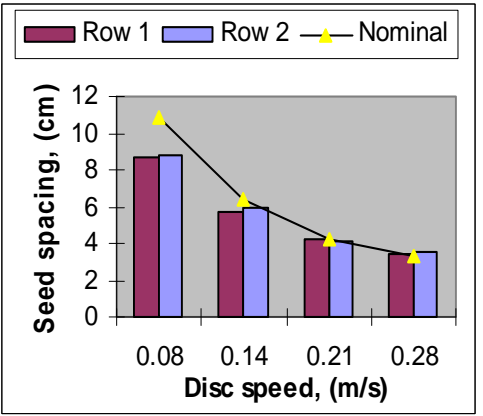

(b)

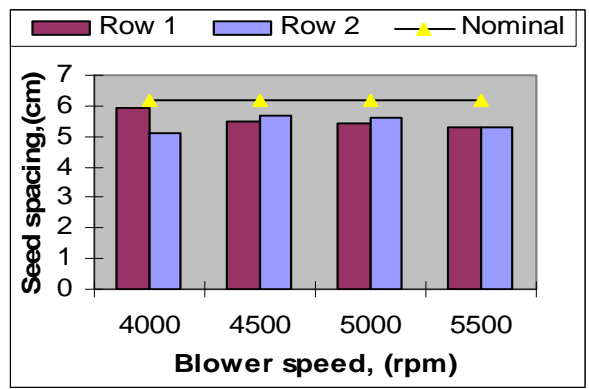

(d)

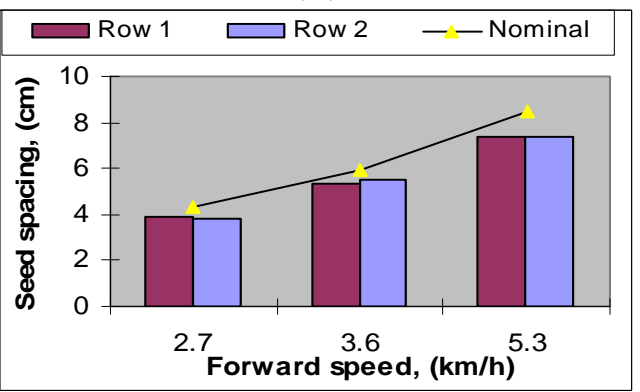

Figure 3. Effect of the hole diameter, blower speed, disc speed and the forward speed on the actual seed spacing for the two rows of the developed prototype.

1- The increasing in the percentage of seed spacing greater than 1.5 times the theoretical seed spacing for the seed plate of $1.2 \mathrm{~mm}$ hole diameter.

2- The decreasing in the percentage of seed spacing smaller than 1.5 times the theoretical seed spacing for the seed plates of 0.8 and 1.0 mm hole diameters.

3- The hole diameters of 0.8 and $1.0 \mathrm{~mm}$ is less than or equal to $50 \%$ of the geometric mean diameter $(2.02 \mathrm{~mm})$ of onion seed, which 
resulting in lower values of seed miss indices. On the other hand, the hole diameter of $1.2 \mathrm{~mm}$ is bigger than $50 \%$ of the geometric mean diameter $(2.02 \mathrm{~mm})$ of onion seed, which producing in higher values of seed miss indices.

The seed miss index decreased with an increase in the blower speed for the tow rows (Figure $4 \mathrm{~b}$ ). There was none potential difference in the seed miss index between the two rows under different levels of blower speeds. These results are in agreement with previous finding by Singh et al., (2005). The effect of the disc speed on the seed miss index for the two rows is shown in Figure (4c). The highest values of the seed miss index were obtained with the disc speed of $0.28 \mathrm{~m} / \mathrm{s}$ for the two rows. However, the lowest values of the seed miss index were obtained with the disc speed of $0.08 \mathrm{~m} / \mathrm{s}$. This result due to that the seed plate at high disc speed does not get enough time to pick up seeds, which resulting in higher miss indices. Figure (3d) indicates the relation between the seed miss index and the forward speed of developed prototype for the two rows. It shows that the lowest values of the seed miss indices were obtained at $3.6 \mathrm{~km} / \mathrm{h}$ followed by $5.3 \mathrm{~km} / \mathrm{h}$ and $2.7 \mathrm{~km} / \mathrm{h}$ forward speeds, respectively. The increase in the forward speed from 2.7 to $3.6 \mathrm{~km} / \mathrm{h}$ caused a decrease in the seed miss indices by $32 \%$ for the two rows. However, the seed miss indices increased by $21 \%$ when the forward speed changed from 3.6 to 5.3 $\mathrm{km} / \mathrm{h}$. This result is in agreement with the previous finding by Chhinnan et al., (1975) and Karayel and Ozmerzi (2001).

Multi-regression analysis were carried out to derive a relation between the seed miss index with respect to forward speed, blower speed and disc speed at different hole diameters for the two rows under experimental conditions. The derived equations are:

For $0.8 \mathrm{~mm}$ hole diameter

$$
\begin{aligned}
\mathrm{MISS}= & -2.7-4.24 \mathrm{FS}+0.0088 \mathrm{BS}+0.64 \mathrm{DS}-0.00031(\mathrm{FS} * \mathrm{BS})-0.299(\mathrm{FS} * \mathrm{DS}) \\
& -0.000121(\mathrm{BS} * \mathrm{DS})+0.530(\mathrm{FS})^{2}+0.0116(\mathrm{DS})^{2}-0.000001(\mathrm{BS})^{2} \\
& +.000064(\mathrm{FS} * \mathrm{BS} * \mathrm{DS}) \quad\left(\mathrm{R}^{2}=81.1 \%\right)
\end{aligned}
$$

For $1.0 \mathrm{~mm}$ hole diameter

$$
\begin{aligned}
\mathrm{MISS}= & 114-21.7 \mathrm{FS}-0.0313 \mathrm{BS}+0.32 \mathrm{DS}+0.00004(\mathrm{FS} * \mathrm{BS})+0.105(\mathrm{FS} * \mathrm{DS}) \\
& +0.000075(\mathrm{BS} * \mathrm{DS})+2.54(\mathrm{FS}) 2-0.00848(\mathrm{DS}) 2+0.000003(\mathrm{BS}) 2- \\
& 0.000022\left(\mathrm{FS}^{*} \mathrm{BS} * \mathrm{DS}\right) \quad(\mathrm{R} 2=89.3 \%)
\end{aligned}
$$


(a)

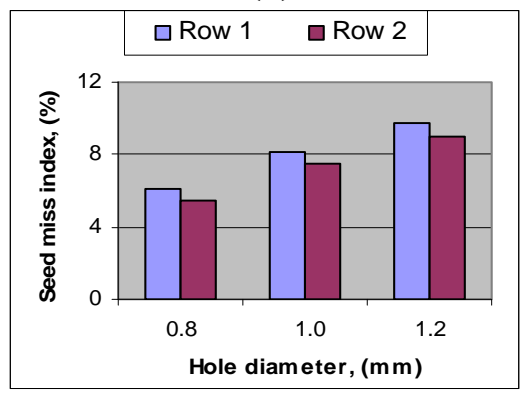

(c)

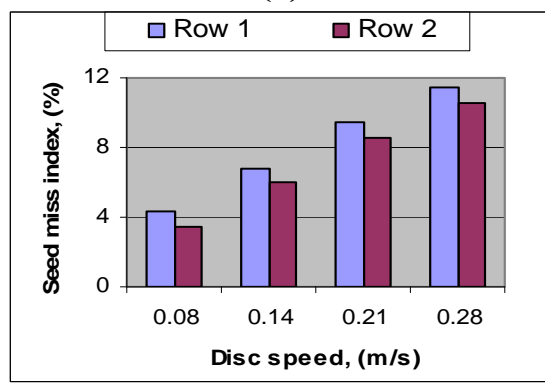

(b)

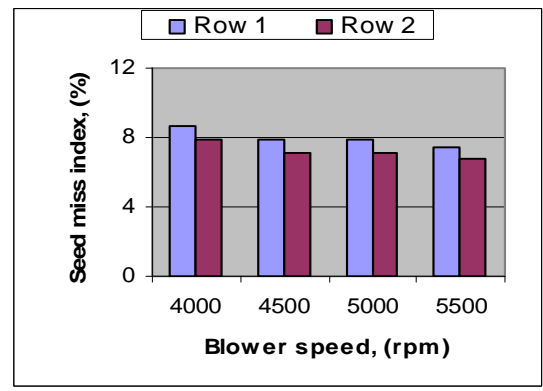

(d)

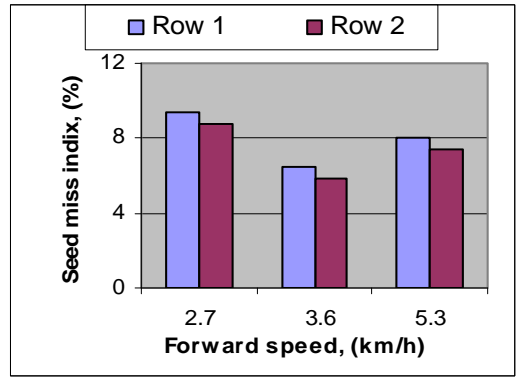

Figure 4. Effect of the hole diameter, blower speed, disc speed and the forward speed on the seed miss index for the two rows of the developed prototype.

For $1.2 \mathrm{~mm}$ hole diameter

$$
\begin{aligned}
\text { MISS }= & -143+0.9 \mathrm{FS}+0.0532 \mathrm{BS}+5.38 \mathrm{DS}-0.00248(\mathrm{FS} * \mathrm{BS})-0.746 \\
& (\mathrm{FS} * \mathrm{DS})-0.000705(\mathrm{BS} * \mathrm{DS})+1.80(\mathrm{FS}) 2-0.0267(\mathrm{DS}) 2-0.000004 \\
& (\mathrm{BS}) 2+0.000108\left(\mathrm{FS}{ }^{\mathrm{BS}} * \mathrm{DS}\right) \quad(\mathrm{R} 2=70.1 \%) \\
& \text { Where:MISS }=\text { miss seed index, }(\%) .
\end{aligned}
$$

The seed multiple index

Figure (5a) shows the influence of the hole diameter of the seed plate on the seed multiple index for the two rows. The lowest values of the seed multiple index was obtained with $1.0 \mathrm{~mm}$ hole diameter. However, the highest and the middle values of the seed multiple indices were resulted with 1.2 and $0.8 \mathrm{~mm}$ hole diameters, respectively. This may attributed to the decreasing in the percentage of seed spacing that are less than or equal to half of the theoretical seed spacing for $1.0 \mathrm{~mm}$ hole diameter and vice versa for $0.8 \mathrm{~mm}$ and $1.2 \mathrm{~mm}$ hole diameters. The effect of the blower speed on the seed multiple index showed inverse trends as a compared with that for the seed miss index at different blower speeds 
(Figure 5b). Thus, the lowest values of the seed multiple indices were obtained at 4000 and 4500-rpm blower speeds. This result may attribute to the increasing in the vacuum pressure as the blower speeds increased, which resulting an increase in the multiple indices. Figure (5c) shows the seed multiple index with different disc speed for the two rows of the developed prototype. The highest values of the seed multiple indices were obtained with the disc speed of $0.08 \mathrm{~m} / \mathrm{s}$ for the two rows. However, the lowest values of the seed multiple indices were obtained with the disc speed of $0.28 \mathrm{~m} / \mathrm{s}$ for the two rows. The seed multiple indices decreased by $32 \%$ and $29 \%$ as disc speed increased from 0.08 to $0.28 \mathrm{~m} / \mathrm{s}$ for first and second rows, respectively. These results due to that the seed plate at low disc speed get enough time to pick up more than one seed, which resulting a higher in multiple indices. These results also are in agreement with previous finding by Barut and Ozmerzi (2004) and Singh and Sarawat (2005). Results of the seed multiple index with the forward speed indicates the lowest values were obtained at $3.6 \mathrm{~km} / \mathrm{h}$ forward speed. However, there was none potential change in the seed multiple indices between 2.7 and $5.3 \mathrm{~km} / \mathrm{h}$ forward speeds (Figure $5 \mathrm{~d}$ ). Multi-regression analysis were carried out to derive a relation between the seed multiple index with respect to forward speed, blower speed and disc speed at different hole diameters for the two rows under experimental conditions. The derived equations are:

For $0.8 \mathrm{~mm}$ hole diameter

$$
\begin{aligned}
\mathrm{MUL}= & 48.9-12.3 \mathrm{FS}+0.0004 \mathrm{BS}-2.86 \mathrm{DS}-0.00123(\mathrm{FS} * \mathrm{BS})+0.530(\mathrm{FS} * \mathrm{DS}) \\
& +0.000122(\mathrm{BS} * \mathrm{DS})+1.47(\mathrm{FS})^{2}+0.0286(\mathrm{DS})^{2}+0.000001(\mathrm{BS})^{2}- \\
& 0.000041(\mathrm{FS} * \mathrm{BS} * \mathrm{DS}) \quad\left(\mathrm{R}^{2}=53.3 \%\right)
\end{aligned}
$$

For $1.0 \mathrm{~mm}$ hole diameter

$$
\begin{aligned}
\mathrm{MUL}= & 110-31.5 \mathrm{FS}-0.0181 \mathrm{BS}-3.09 \mathrm{DS}+0.00292(\mathrm{FS} * \mathrm{BS})+0.736(\mathrm{FS} * \mathrm{DS}) \\
& +0.000569(\mathrm{BS} * \mathrm{DS})+2.11(\mathrm{FS}) 2+0.00517(\mathrm{DS}) 2+0.000001(\mathrm{BS}) 2- \\
& 0.000153(\mathrm{FS} * \mathrm{BS} * \mathrm{DS}) \quad(\mathrm{R} 2=75.9 \%)
\end{aligned}
$$

For $1.2 \mathrm{~mm}$ hole diameter

$$
\begin{aligned}
\mathrm{MUL}= & 153-13.7 \mathrm{FS}-0.0505 \mathrm{BS}+0.82 \mathrm{DS}+0.00033(\mathrm{FS} * \mathrm{BS})-0.386(\mathrm{FS} * \mathrm{DS}) \\
& -0.000192(\mathrm{BS} * \mathrm{DS})+2.00(\mathrm{FS}) 2+0.0170(\mathrm{DS}) 2+0.000006(\mathrm{BS}) 2+ \\
& 0.000034(\mathrm{FS} * \mathrm{BS} * \mathrm{DS}) \quad(\mathrm{R} 2=71.3 \%) \\
& \text { Where: } \mathrm{MUL}=\text { multiple seed index, }(\%) .
\end{aligned}
$$


(a)

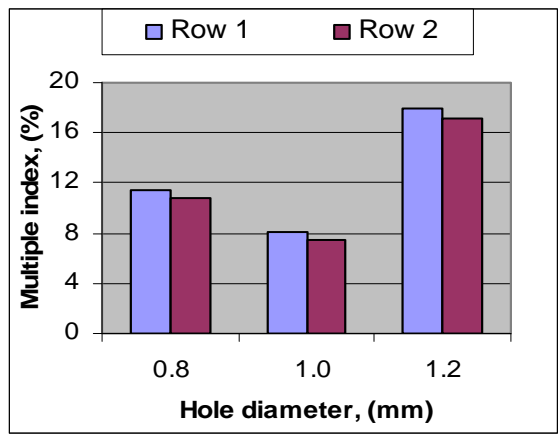

(c)

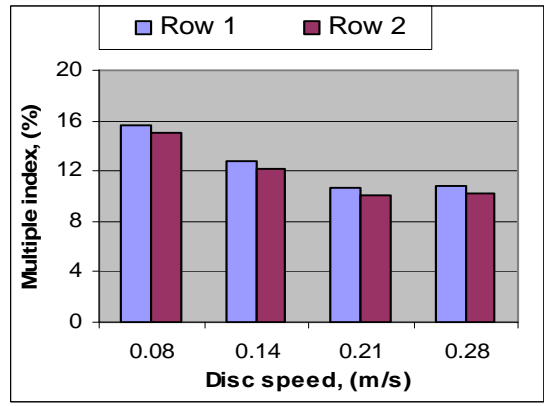

(b)

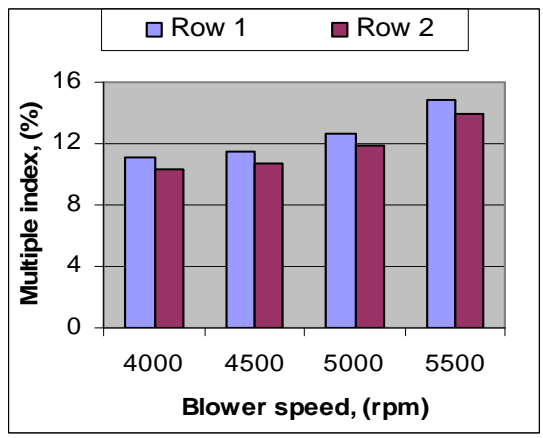

(d)

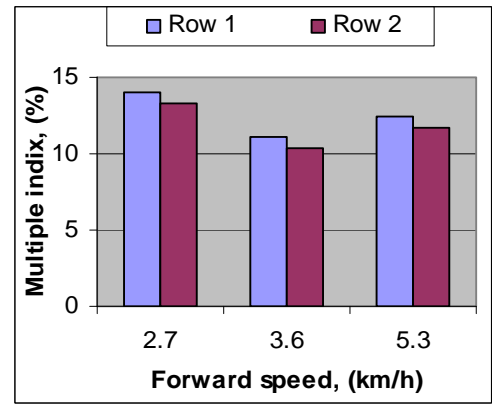

Figure 5. Effect of the hole diameter, blower speed, disc speed and the forward speed on the seed multiple index for the two rows of the developed prototype.

The quality of feed index

Figure (6) shows the effect of hole diameter, blower speed, disc speed and forward speed on the quality of feed index for the two rows of the developed prototype. It shows that there was none potential difference in the quality of feed index between the seed plates of 0.8 and $1.0 \mathrm{~mm}$ hole diameters (Figure 6a). However, the seed plate of $1.2 \mathrm{~mm}$ hole diameter produced the lowest values of the quality of feed index for the two rows. These results due to the increasing in seed miss and seed multiple indices as the hole diameter increased for the two rows (Figures 4a and Figure $5 a)$. The quality of feed index decreased with an increase in the blower speed for the two rows (Figure 6b). The change in the blower speed from 4000 to 5500-rpm does not produce a decrease in the quality of feed index by more than $3 \%$ for the two rows. These results may be attributed to that the decreasing ratio in the seed miss index by increasing the 
blower speed equal the increasing ratio in the seed multiple index (Figure $4 b$ and Figure 5b).

(a)

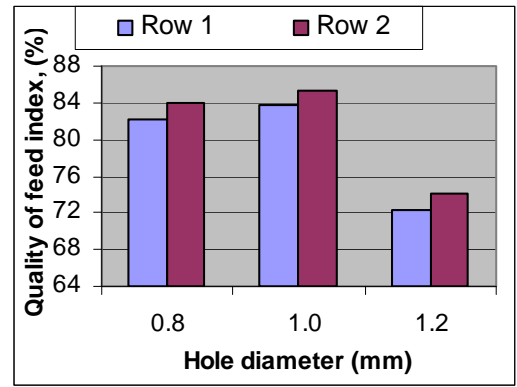

(c)

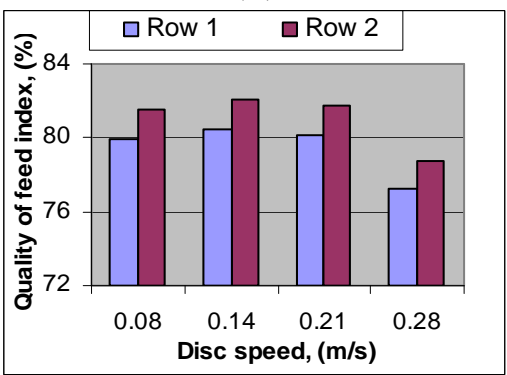

(b)

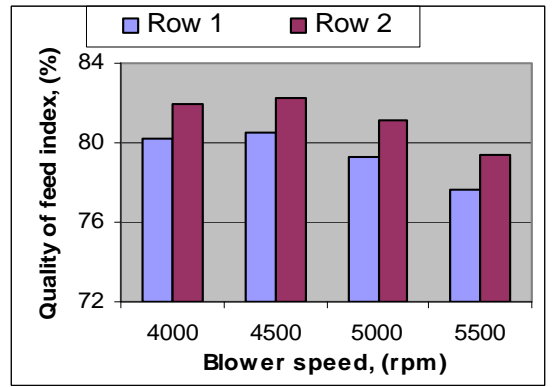

(d)

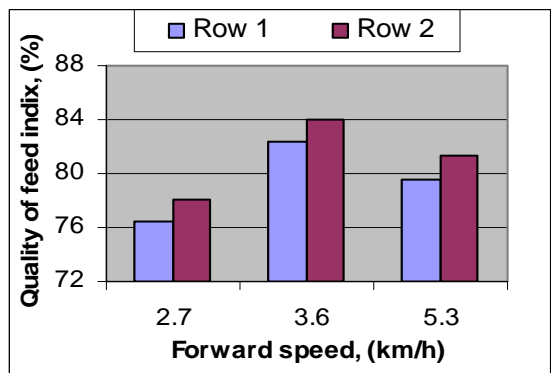

Figure 6. Effect of the hole diameter, blower speed, disc speed and the forward speed on the quality of feed index for the two rows of the developed prototype.

Similar trends were obtained in the quality of feed index at different disc speeds compared with that at various levels of blower speeds except for the highest values of the quality of feed indices were resulted at $0.14 \mathrm{~m} / \mathrm{s}$ disc speed for the two rows (Figure 6c). There was none potential change in the quality of feed index at different levels of forward speeds (Figure 6d). However, the quality of feed index for the second row does not increase by not more than $3 \%$ as a compared with the first row at different forward speeds. These results may be attributed to that the increasing ratio in the seed miss index by increasing forward speed equal the decreasing ratio in the seed multiple index (Figure $4 d$ and Figure 5d). Multi-regression analysis were carried out to derive a relation between the quality of feed index with respect to forward speed, blower speed and disc speed at different hole diameters for the two rows under experimental conditions. The derived equations are: 
For $0.8 \mathrm{~mm}$ hole diameter

$$
\begin{aligned}
& \mathrm{QUA}=69.5+14.8 \mathrm{FS}-0.0138 \mathrm{BS}+2.25 \mathrm{DS}+0.00146(\mathrm{FS} * \mathrm{BS})-0.254(\mathrm{FS} * \mathrm{DS}) \\
& \text { - } 0.000007(\mathrm{BS} * \mathrm{DS}) \\
& -1.77(\mathrm{FS})^{2}-0.0453(\mathrm{DS})^{2} \\
& +0.000001(\mathrm{BS})^{2}-0.000013(\mathrm{FS} * \mathrm{BS} * \mathrm{DS}) \\
& \left(\mathrm{R}^{2}=71.3 \%\right)
\end{aligned}
$$

For $1.0 \mathrm{~mm}$ hole diameter

$$
\begin{aligned}
\mathrm{QUA}= & -104+58.2 \mathrm{FS}+0.0352 \mathrm{BS}+5.13 \mathrm{DS}-0.00363(\mathrm{FS} * \mathrm{BS})-1.38(\mathrm{FS} * \mathrm{DS})- \\
& 0.00100(\mathrm{BS} * \mathrm{DS})-4.78(\mathrm{FS}) 2-0.0141(\mathrm{DS}) 2-0.000003(\mathrm{BS}) 2+ \\
& 0.000282\left(\mathrm{FS}^{*} \mathrm{BS} * \mathrm{DS}\right) \quad(\mathrm{R} 2=88.2 \%)
\end{aligned}
$$

For $1.2 \mathrm{~mm}$ hole diameter

$$
\begin{aligned}
\mathrm{QUA}= & 114+4.1 \mathrm{FS}-0.0072 \mathrm{BS}-6.04 \mathrm{DS}+0.00288(\mathrm{FS} * \mathrm{BS})+1.23(\mathrm{FS} * \mathrm{DS})+ \\
& 0.000940(\mathrm{BS} * \mathrm{DS}) \quad-0.21(\mathrm{FS}) 2-0.0030(\mathrm{DS}) 2-0.000001(\mathrm{BS}) 2 \\
& -0.000161(\mathrm{FS} * \mathrm{BS} * \mathrm{DS})(\mathrm{R} 2=69.1 \%)
\end{aligned}
$$$$
\text { Where: QUA = quality of feed index (\%). }
$$

\section{The precision in spacing}

The precision in spacing in relation to different levels of hole diameters, blower speeds, disc speeds and forward speeds for the two rows of the developed prototype are shown in Figure (7). It indicates that, there was none potential difference in the precision in spacing between the first and the second rows at different operational parameters. The seed plate of 1.0 $\mathrm{mm}$ hole diameter produced the lowest values of the precision in spacing for the two rows. However, the highest values of precision in spacing were obtained with the seed plates of 0.8 hole diameter (Figure 7a). This may be attributed to the decreasing in the standard deviation of spacing more than half but not more than 1.5 times of the theoretical spacing for $1.0 \mathrm{~mm}$ hole diameter. However, the standard deviations of spacing more than half but not more than 1.5 times of the theoretical spacing increased for 0.8 and $1.2 \mathrm{~mm}$ hole diameters for the two rows. The effect of blower speed on the precision in spacing showed that the 4500 and 5000-rpm blower speeds resulted in the lowest values of the precision in spacing. However, the highest values of the precision in spacing were obtained with 4000 and 5500-rpm blower speeds for the two rows (Figure 7b). These results duo to that the highest values in the quality of feed index were obtained at 4500-rpm blower speed and the lowest values were resulted at 5500-rpm blower speed for the two rows (Figure 6b). Figure (7c) indicates the relation between the precision in spacing with the disc 
speed. The highest values in the precision in spacing were resulted with 0.14 and $0.21 \mathrm{~m} / \mathrm{s}$ disc speeds. On the other hand, the 0.08 and $0.28 \mathrm{~m} / \mathrm{s}$ disc speeds gave the lowest values of the precision in spacing for the two rows. These results duo to that the highest values of the quality of feed index were obtained at 0.14 and $0.21 \mathrm{~m} / \mathrm{s}$ disc speeds. However, the lowest values in the precision in spacing were resulted at $0.28 \mathrm{~m} / \mathrm{s}$ disc speed (Figure 6c).

Results of the precision in spacing with different forward speeds (Figure $7 \mathrm{~d}$ ) showed that the forward speed of $2.7 \mathrm{~km} / \mathrm{h}$ gave the lowest values of the precision in spacing. However, there was none potential difference in the precision in spacing between 3.6 and $5.3 \mathrm{~km} / \mathrm{h}$ forward speeds. This is duo to that the lowest values of the quality of feed index were obtained at $2.7 \mathrm{~km} / \mathrm{h}$ forward speed. However, there are no changes in the quality of feed indices between 3.6 and $5.3 \mathrm{~km} / \mathrm{h}$ forward speeds for the two rows (Figure 6d). Multi-regression analysis were carried out to derive a relation between the precision in spacing with respect to forward speed, blower speed and disc speed at different hole diameters for the two rows under experimental conditions. However, unfortunately, the correlation coefficients were too low.

\section{The vacuum pressure}

Figure (8) shows the effect of the hole diameter and blower speed on the vacuum pressure in the hole for the two rows of the developed prototype. It indicates that there was none appreciable change in the vacuum pressure between two rows at different blower speeds and with various hole diameters. The vacuum pressure in the hole increased with an increase in the blower speeds for the two rows (Figure 8a). The increase in the blower speed from 4000-rpm to 550-rpm produced an increase in the vacuum pressure in the hole by $58 \%$ for the two rows. This may be attributed to the increasing in the vacuum velocity as the blower speed increased for the two rows. The vacuum pressure in the hole decreased with an increase in the hole diameters (Figure $8 \mathrm{~b}$ ). The highest values in the vacuum pressure were obtained with 0.8 hole diameter. However, there was no change in the vacuum pressure between $1.0 \mathrm{~mm}$ and $1.2 \mathrm{~mm}$ hole diameters. This result duo to the increasing in the conical entrance 
area of the holes from $1.2 \mathrm{~mm}^{2}$ to $2.6 \mathrm{~mm}^{2}$ as the hole diameter increased from .08 to $1.2 \mathrm{~mm}$, which resulting an increase in the vacuum pressure.

(a)

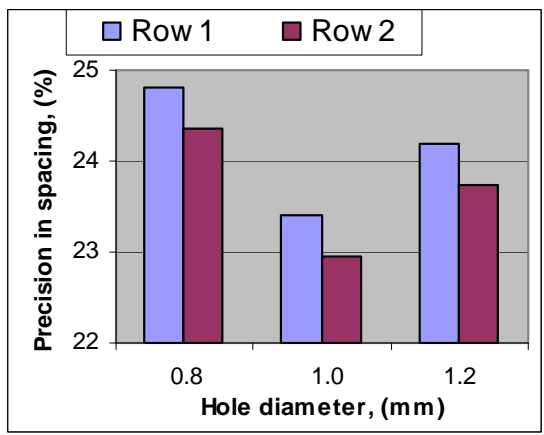

(c)

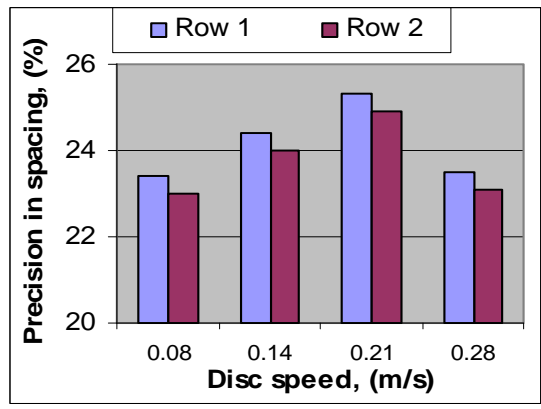

(b)

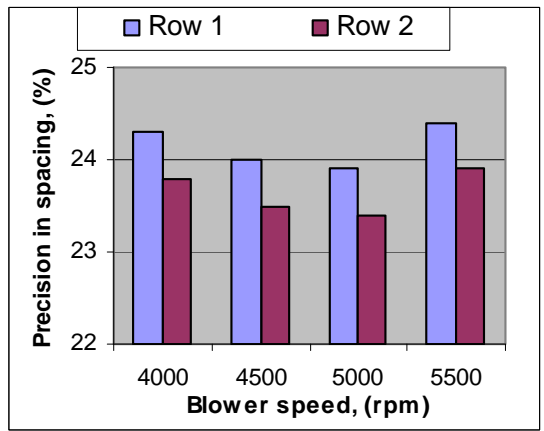

(d)

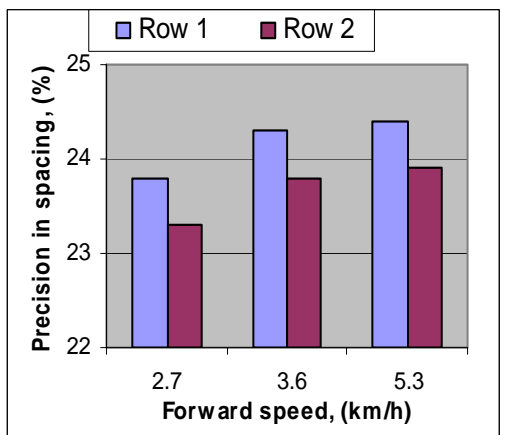

Figure 7. Effect of the hole diameter, blower speed, disc speed and the forward speed on the precision in spacing for the two rows of the developed prototype.

Multi-regression analysis was carried out to derive a relation between the vacuum pressure in the hole with respect to blower speed and the hole diameters under experimental conditions. The derived equation is: $\mathrm{V}=-257+209 \mathrm{H}+0.0777 \mathrm{BS}-56.2(\mathrm{H})^{2}-0.000003(\mathrm{BS})^{2}-0.0297\left(\mathrm{H}^{*} \mathrm{BS}\right)$ $\left(\mathrm{R}^{2}=98.1 \%\right)$

Where: $\mathrm{V}=$ vacuum pressure, (mbar),

$\mathrm{BS}=$ blower speed $(\mathrm{rpm})$, and

$\mathrm{H}=$ hole diameter $(\mathrm{mm})$.

\section{Statistical analysis}

The least significant difference (LSD) test was performed for the mean values of actual seed spacing, seed miss index, seed multiple index, 
quality of feed index and precision in spacing in relation to hole diameter, forward speed, blower speed and disc speed under experimental conditions.

(a)

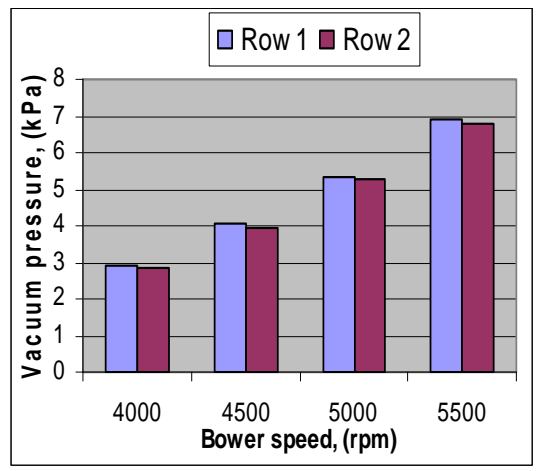

(b)

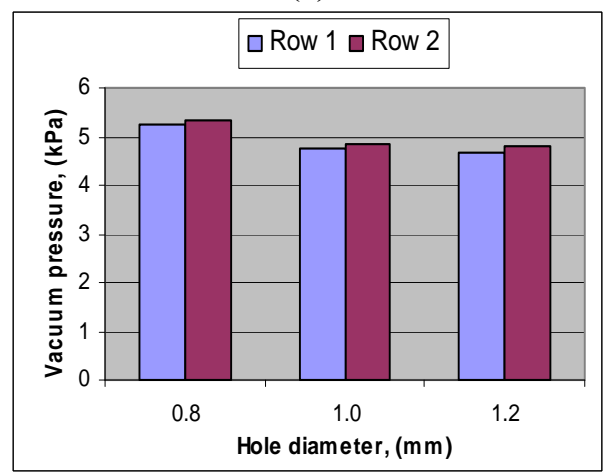

Figure 8. Effect of the hole diameter and the blower speed on the vacuum pressure in the hole for the two rows of the developed prototype.

On the other hand, the least significant difference for the vacuum pressure was performed in relation to hole diameter and the blower speed with three replicates. Results of this analysis are shown in Table 1.

\section{CONCLUSION}

Results of this study could be summarized as follows:

- The highest values of the actual seed spacing were obtained with the seed plate of $1.0 \mathrm{~mm}$ hole diameter, 4000-rpm blower speed, $0.08 \mathrm{~m} / \mathrm{s}$ disc speed and $5.3 \mathrm{~km} / \mathrm{h}$ forward speed for the second row. However, the closest values of the actual seed spacing in relation to the nominal seed spacing were resulted with the seed plate of 1.0 $\mathrm{mm}$ hole diameter, 4500-rpm blower speed, $0.21 \mathrm{~m} / \mathrm{s}$ disc speed and $3.6 \mathrm{~km} / \mathrm{h}$ forward speed for the second row of developed prototype. 
Table 1. The least significant difference test (LSD) for the actual seed spacing, seed miss index, seed multiple index, quality of feed index, precision in spacing and the vacuum pressure.

\begin{tabular}{|c|c|c|c|c|c|c|c|}
\hline Factor & Variable & Mean & $\begin{array}{c}\text { LSD } \\
(\mathbf{0 . 0 1})\end{array}$ & Factor & Variable & Mean & $\begin{array}{c}\text { LSD } \\
(\mathbf{0 . 0 1})\end{array}$ \\
\hline \multirow{16}{*}{$\begin{array}{l}\text { Actual } \\
\text { seed } \\
\text { spacing } \\
\text { (cm) }\end{array}$} & row1 & $5.496 \mathrm{a}$ & \multirow[t]{2}{*}{0.21} & \multirow{16}{*}{$\begin{array}{l}\text { Quality of } \\
\text { feed index } \\
(\%)\end{array}$} & row1 & $78.494 \mathrm{a}$ & \multirow[t]{2}{*}{1.81} \\
\hline & row2 & $5.573 \mathrm{a}$ & & & row2 & $80.345 \mathrm{a}$ & \\
\hline & $0.8 \mathrm{~mm}$ & $5.377 \mathrm{a}$ & \multirow[t]{3}{*}{0.26} & & $0.8 \mathrm{~mm}$ & $82.165 \mathrm{a}$ & \multirow[t]{3}{*}{2.21} \\
\hline & $1.0 \mathrm{~mm}$ & $5.932 \mathrm{a}$ & & & $1.0 \mathrm{~mm}$ & $83.692 \mathrm{a}$ & \\
\hline & $1.2 \mathrm{~mm}$ & $5.295 b$ & & & $1.2 \mathrm{~mm}$ & $72.402 \mathrm{~b}$ & \\
\hline & $2.7 \mathrm{~km} / \mathrm{h}$ & $3.859 \mathrm{c}$ & \multirow[t]{3}{*}{0.26} & & $2.7 \mathrm{~km} / \mathrm{h}$ & $76.405 \mathrm{c}$ & \multirow[t]{3}{*}{2.21} \\
\hline & $3.6 \mathrm{~km} / \mathrm{h}$ & $5.381 \mathrm{~b}$ & & & $3.6 \mathrm{~km} / \mathrm{h}$ & $82.289 a$ & \\
\hline & $5.3 \mathrm{~km} / \mathrm{h}$ & $7.364 \mathrm{a}$ & & & $5.3 \mathrm{~km} / \mathrm{h}$ & $79.565 b$ & \\
\hline & $4000 \mathrm{rpm}$ & $5.786 \mathrm{a}$ & \multirow[t]{4}{*}{0.3} & & $4000 \mathrm{rpm}$ & $80.235 \mathrm{a}$ & \multirow[t]{4}{*}{2.55} \\
\hline & $4500 \mathrm{rpm}$ & $5.646 \mathrm{a}$ & & & $4500 \mathrm{rpm}$ & $80.472 \mathrm{a}$ & \\
\hline & $5000 \mathrm{rpm}$ & $5.406 \mathrm{a}$ & & & $5000 \mathrm{rpm}$ & $79.349 \mathrm{a}$ & \\
\hline & $5500 \mathrm{rpm}$ & $5.301 \mathrm{a}$ & & & $5500 \mathrm{rpm}$ & $77.622 \mathrm{a}$ & \\
\hline & $0.08 \mathrm{~m} / \mathrm{s}$ & $8.703 a$ & \multirow[t]{4}{*}{0.3} & & $0.08 \mathrm{~m} / \mathrm{s}$ & $79.854 \mathrm{a}$ & \multirow[t]{4}{*}{2.55} \\
\hline & $0.14 \mathrm{~m} / \mathrm{s}$ & $5.785 b$ & & & $0.14 \mathrm{~m} / \mathrm{s}$ & $80.452 \mathrm{a}$ & \\
\hline & $0.21 \mathrm{~m} / \mathrm{s}$ & $4.192 \mathrm{c}$ & & & $0.21 \mathrm{~m} / \mathrm{s}$ & $80.068 \mathrm{a}$ & \\
\hline & $0.28 \mathrm{~m} / \mathrm{s}$ & $3.460 \mathrm{~d}$ & & & $0.28 \mathrm{~m} / \mathrm{s}$ & $77.214 b$ & \\
\hline \multirow{16}{*}{$\begin{array}{c}\text { Seed } \\
\text { miss } \\
\text { index } \\
(\%)\end{array}$} & row1 & $8.393 \mathrm{a}$ & \multirow[t]{2}{*}{0.99} & \multirow{16}{*}{$\begin{array}{c}\text { Precision } \\
\text { in spacing } \\
(\%)\end{array}$} & row1 & $24.310 \mathrm{a}$ & \multirow[t]{2}{*}{0.76} \\
\hline & row2 & $7.545 \mathrm{a}$ & & & row2 & $23.965 \mathrm{a}$ & \\
\hline & $0.8 \mathrm{~mm}$ & $6.118 \mathrm{c}$ & \multirow[t]{3}{*}{1.21} & & $0.8 \mathrm{~mm}$ & $24.786 \mathrm{a}$ & \multirow[t]{3}{*}{0.93} \\
\hline & $1.0 \mathrm{~mm}$ & $8.050 \mathrm{~b}$ & & & $1.0 \mathrm{~mm}$ & $23.395 b$ & \\
\hline & $1.2 \mathrm{~mm}$ & $9.739 a$ & & & $1.2 \mathrm{~mm}$ & $24.231 \mathrm{a}$ & \\
\hline & $2.7 \mathrm{~km} / \mathrm{h}$ & $9.421 \mathrm{a}$ & \multirow[t]{3}{*}{1.21} & & $2.7 \mathrm{~km} / \mathrm{h}$ & $23.776 \mathrm{a}$ & \multirow[t]{3}{*}{0.93} \\
\hline & $3.6 \mathrm{~km} / \mathrm{h}$ & $6.452 \mathrm{c}$ & & & $3.6 \mathrm{~km} / \mathrm{h}$ & $24.273 \mathrm{a}$ & \\
\hline & $5.3 \mathrm{~km} / \mathrm{h}$ & $8.033 b$ & & & $5.3 \mathrm{~km} / \mathrm{h}$ & $24.364 \mathrm{a}$ & \\
\hline & $4000 \mathrm{rpm}$ & $8.661 \mathrm{a}$ & \multirow[t]{4}{*}{1.40} & & $4000 \mathrm{rpm}$ & $24.289 \mathrm{a}$ & 1.07 \\
\hline & $4500 \mathrm{rpm}$ & $7.860 \mathrm{a}$ & & & $4500 \mathrm{rpm}$ & $23.983 \mathrm{a}$ & \\
\hline & $5000 \mathrm{rpm}$ & $7.887 \mathrm{a}$ & & & $5000 \mathrm{rpm}$ & $23.903 \mathrm{a}$ & \\
\hline & $5500 \mathrm{rpm}$ & $7.468 \mathrm{a}$ & & & $5500 \mathrm{rpm}$ & $24.375 \mathrm{a}$ & \\
\hline & $0.08 \mathrm{~m} / \mathrm{s}$ & $4.282 \mathrm{~d}$ & 1.40 & & $0.08 \mathrm{~m} / \mathrm{s}$ & $23.406 \mathrm{ab}$ & 1.07 \\
\hline & $0.14 \mathrm{~m} / \mathrm{s}$ & $6.822 \mathrm{c}$ & & & $0.14 \mathrm{~m} / \mathrm{s}$ & $24.379 \mathrm{a}$ & \\
\hline & $0.21 \mathrm{~m} / \mathrm{s}$ & $9.403 b$ & & & $0.21 \mathrm{~m} / \mathrm{s}$ & $25.258 \mathrm{a}$ & \\
\hline & $0.28 \mathrm{~m} / \mathrm{s}$ & $11.369 \mathrm{a}$ & & & $0.28 \mathrm{~m} / \mathrm{s}$ & $23.507 b$ & \\
\hline Seed & row1 & $12.974 \mathrm{a}$ & 1.27 & Vacuum & row1 & $5.1433 \mathrm{a}$ & 2.98 \\
\hline multiple & row2 & $12.024 \mathrm{a}$ & & pressure & row2 & $5.2353 \mathrm{a}$ & \\
\hline index & $0.8 \mathrm{~mm}$ & $11.490 \mathrm{~b}$ & 1.56 & (kPa) & $0.8 \mathrm{~mm}$ & $5.4167 \mathrm{a}$ & 3.32 \\
\hline$(\%)$ & $1.0 \mathrm{~mm}$ & $8.121 \mathrm{c}$ & & & $1.0 \mathrm{~mm}$ & $4.750 \mathrm{~b}$ & \\
\hline & $1.2 \mathrm{~mm}$ & $17.887 \mathrm{a}$ & & & $1.2 \mathrm{~mm}$ & $3.633 \mathrm{c}$ & \\
\hline & $2.7 \mathrm{~km} / \mathrm{h}$ & $13.972 \mathrm{a}$ & 1.56 & & rep.1 & $4.667 \mathrm{a}$ & 3.32 \\
\hline & $3.6 \mathrm{~km} / \mathrm{h}$ & $11.136 \mathrm{~b}$ & & & rep. 2 & $4.558 \mathrm{a}$ & \\
\hline & $5.3 \mathrm{~km} / \mathrm{h}$ & $12.390 \mathrm{~b}$ & & & rep. 3 & $4.575 \mathrm{a}$ & \\
\hline & $4000 \mathrm{rpm}$ & $11.097 \mathrm{~b}$ & 1.80 & & $4000 \mathrm{rpm}$ & $3.288 \mathrm{~d}$ & 3.83 \\
\hline & $4500 \mathrm{rpm}$ & $11.440 \mathrm{~b}$ & & & $4500 \mathrm{rpm}$ & $4.277 \mathrm{c}$ & \\
\hline & $5000 \mathrm{rpm}$ & $12.693 b$ & & & $5000 \mathrm{rpm}$ & $5.088 \mathrm{~b}$ & \\
\hline & $5500 \mathrm{rpm}$ & $14.767 \mathrm{a}$ & & & $5500 \mathrm{rpm}$ & $5.744 a$ & \\
\hline & $0.08 \mathrm{~m} / \mathrm{s}$ & $15.711 \mathrm{a}$ & 1.80 & & & & \\
\hline & $0.14 \mathrm{~m} / \mathrm{s}$ & $12.764 b$ & & & & & \\
\hline & $0.21 \mathrm{~m} / \mathrm{s}$ & $10.653 \mathrm{c}$ & & & & & \\
\hline & $0.28 \mathrm{~m} / \mathrm{s}$ & $10.869 \mathrm{c}$ & & & & & \\
\hline
\end{tabular}


Means followed by the same letters are not significant at 0.01 level of confidence.

- The lowest values of the seed miss indices were obtained with the second row at $0.8 \mathrm{~mm}$ hole diameter, 5500-rpm blower speed, 0.08 $\mathrm{m} / \mathrm{s}$ disc speed and $3.6 \mathrm{~km} / \mathrm{h}$ forward speed. On the other hand, the lowest values of the seed multiple indices were resulted with the seed plate of $1.0 \mathrm{~mm}$ hole diameter, 4000-rpm blower speed, 0.28 $\mathrm{m} / \mathrm{s}$ disc speed and $3.6 \mathrm{~km} / \mathrm{h}$ forward speed.

- The highest values of the quality of feed indices were obtained with the second row at $1.0 \mathrm{~mm}$ hole diameter, 4500-rpm blower speed, $0.14 \mathrm{~m} / \mathrm{s}$ disc speed and $3.6 \mathrm{~km} / \mathrm{h}$ forward speed. However, the lowest values of the precision in spacing were obtained with the seed plate of $1.0 \mathrm{~mm}$ hole diameter, 4500-rpm blower speed, 0.08 $\mathrm{m} / \mathrm{s}$ disc speed and $2.7 \mathrm{~km} / \mathrm{h}$ forward speed..

- The highest values of the vacuum pressure were resulted with the second row at $1.0 \mathrm{~mm}$ hole diameter and at 5500-rpm blower speed. There was no significant difference in the vacuum pressure between the two rows of the developed prototype.

- Results of statistical analysis showed that the most favorable conditions in terms of operating developed prototype will be 0.21 $\mathrm{m} / \mathrm{s}$ disc speed and at 4500-rpm blower speed with the seed plate of $1.0 \mathrm{~mm}$ hole diameter at $3.6 \mathrm{~km} / \mathrm{h}$ forward speed. It also indicated that there was no appreciable difference between the two rows of the developed prototype under different operational conditions.

\section{REFERENCES}

Shaaban Y A (2009). Development of an appropriate pneumatic planter for small holding in Egypt. Unpublished Ph. D. Thesis. College of Agric, Benha Uni.

Barut Z B; Ozmerzi A (2004). Effect of different operating parameters on seed holding in the single seed metering unit of a pneumatic planter. Turk. J. Agric., (28): 435-441.

Bosoi, E.S., Verniaev, O. V.; Smirnov, 1. 1., and Sultan-Shakh, E. G., 1987, Agricultural machines, theory, construction and calculations, Vol. 1, Oxionian Press Pvt. Ltd., New Delhi : 237-275. 
Bracy R P; Parish R L (1998). Seeding uniformity of precision seeders. Horticultural Technology, 8(2):182-185.

Chhinnan M S; Young J H; Rohrbach R P (1975). Accuracy of seed spacing in peanut planting, Transactions of the ASAE,18(1):828-831.

El-Sahrigi A F (1985). Socico-economic evaluation of farm machinery introduced in project villages from 1980 to 1984. Working paper No (19). Ministry of Agriculture, Cvacuumo, Egypt.

El-Shal M S (1987). A Study on the usability of pneumatic planters under Egyptian prevailing conditions. Egypt. J. App. Second Issue June (2), 1987. 511-520.

Giannini G R; Chancellor W J; Garrett R E (1967). Precision planter using vacuum for seed pickup. Transactions of the ASAE, 10 (5): 607-750.

Kachman S D; Smith J A (1995). Alternative measures of accuracy in plant spacing for planters using single seed metering. Trans. of the ASAE, 38(2): 379-387.

Karayel D; Ozmerzi A (2001). Effect of forward speed and seed spacing on seeding uniformity of a precision vacuum metering unit for melon and cucumber seeds. Journal of the Faculty of Agriculture, 14(2): 63-67.

Karayel D; Barut Z B; Ozmerzi A (2004). Mathematical modeling of vacuum pressure on a precision seeder. Biosystems Engineering 87 (4), $437-444$

Lan Y; Kocher M F; Smith J A (1999).Opto-electronic sensor system for laboratory measurement of planter seed spacing with small seeds. Journal of Agricultural Engineering Research,72(1):1 19-127.

Onal I (1987). Sowing-planting-fertilizing machineries. Ege University, Agriculture Faculty Publication No. 490.pp. 372.(EU Agriculture Faculty Press: Izmir, Turkey.

Parish R L; Bracy R P; McCoy J E (1991). High-density planting in a precision cultural system for vegetable production. Horticultural Technology, 1(1): 54-58. 
Singh R C; Singh G; Saraswat D C (2005). Optimization of design and operational parameters of a pneumatic seed metering deice for planting cottonseeds. Bio-systems Engineering, 92(4): 429-433.

Srivastava A K; Goering C E; Rohrbach R P (1993). Engineering Principals of Agricultural Machines. ASAE Textbook Number 6. Pamela De Vore-Hansen, Editor Information Publishing Group, USA. pp: (235).

Soos P; Sziile Z S; Fiizy J (1989). A comparative evaluation of modern sugar beet drills. Bulletin of the University of Agricultural Science, Godollo, 1, 166-170.

Wanjura D F; Hudspeth E B (1969). Performance of vacuum wheels metering individual cottonseed. Transactions of the ASAE, 12(6): 775-777.

\section{الملخص العزبي}

تطوير نموذج لألة زراعة دقيقة لبذور البصل تعمل بشفط الهواء

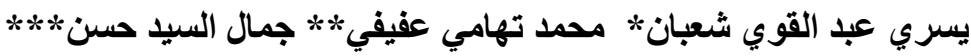

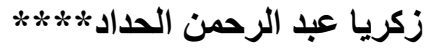

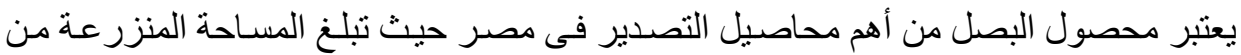

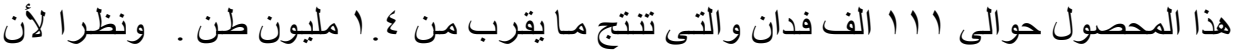

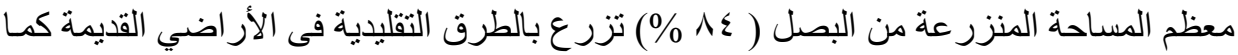

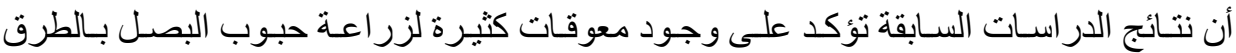

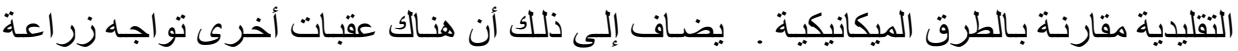

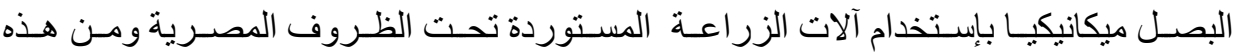

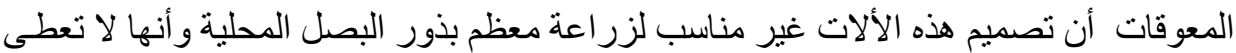

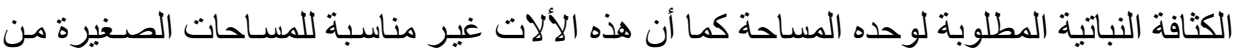

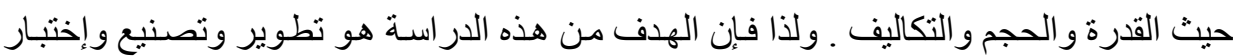

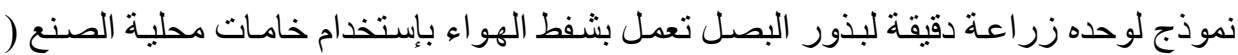

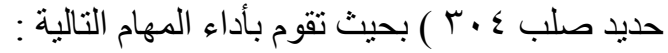

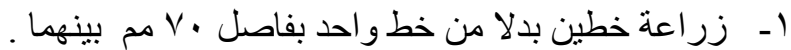

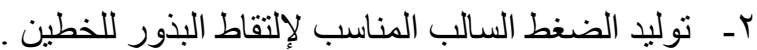

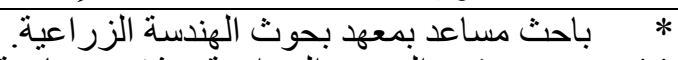
*** * مدرس بقسم الهندسه الزر اعية بمشتهر - جامعة بنها.

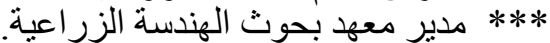

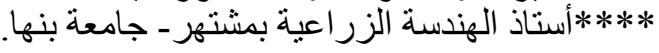




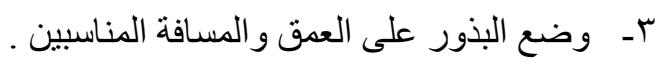

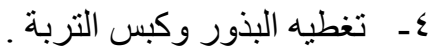

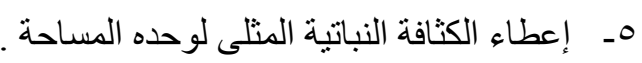
T- يمكن إستخدامها فى المساحات الصغيرة بأدنى تكلفة للتشغيل .

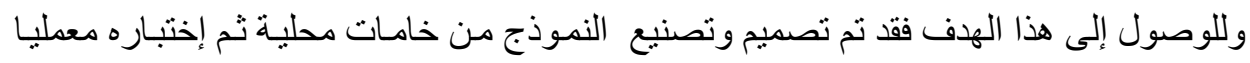

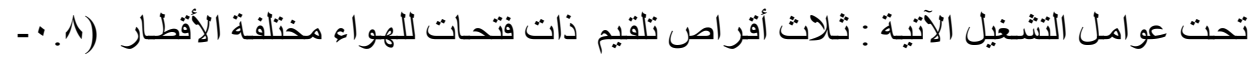

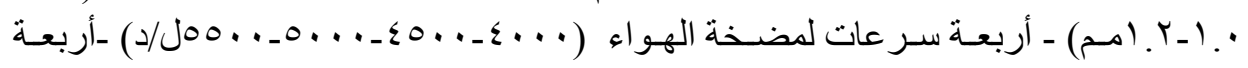

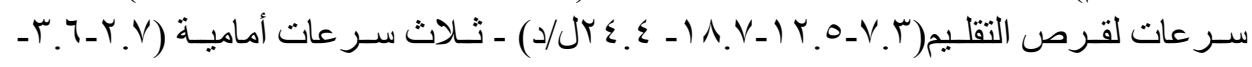

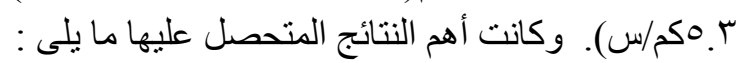

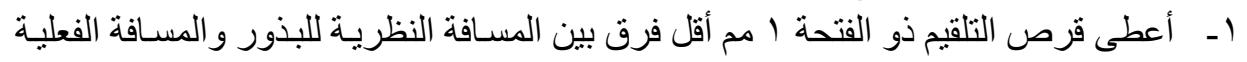

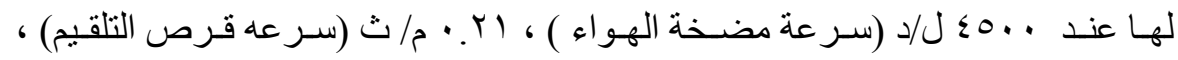
وكذللك عند 7. ب كم /ساعة (سرعة أمامية)

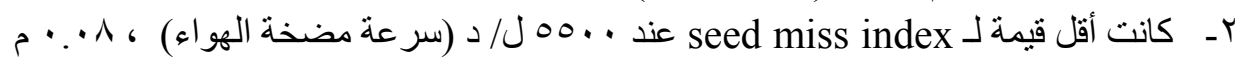

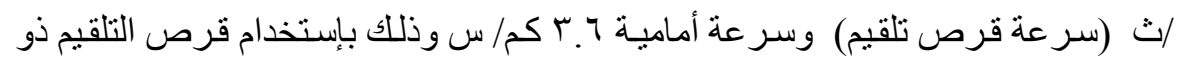

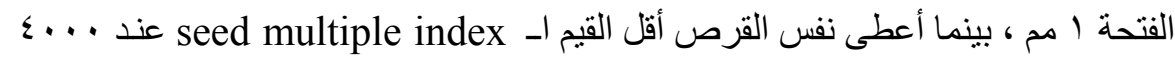

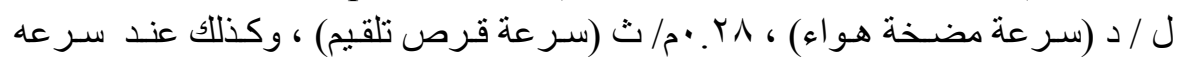

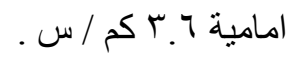

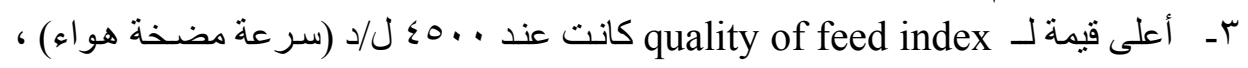

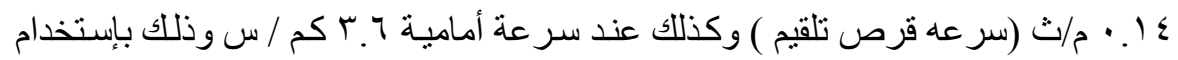

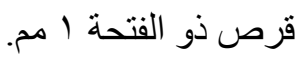

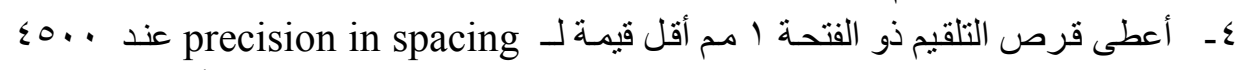

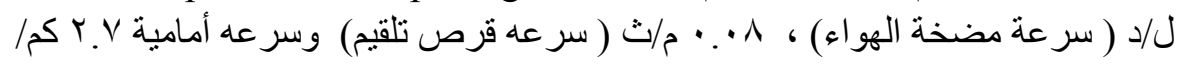
. س ○ـ أعطى قرص التلقيم ذو الفتحة ا مم أقل قيمة للضغط السـالب عند سرعة مضخة الهواء

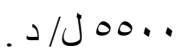

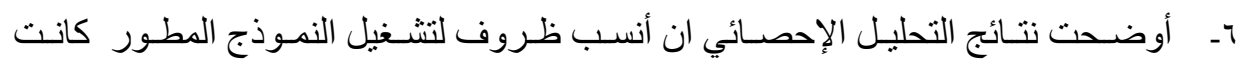

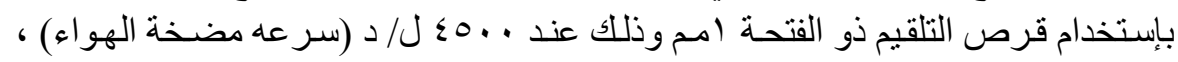

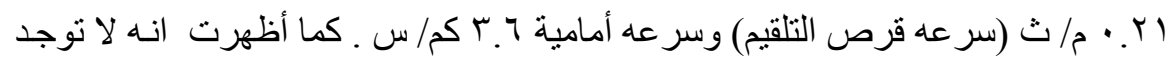

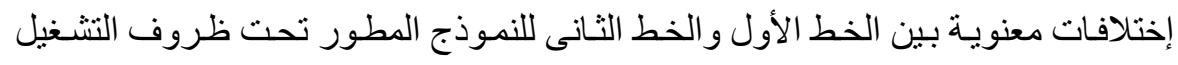

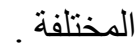

